\title{
Mechanical Behaviors of Al-Based Metal Composites Fabricated by Stir Casting Technique
}

\author{
Mostafizur Rahman* and Sadnan Mohosin Mondol \\ Department of Mechanical Engineering, Chittagong University of Engineering \& Technology, Chattogram-4349, Bangladesh
}

Received: December 02, 2020, Revised: December 17, 2020, Accepted: December 18, 2020, Available Online: December 20,2020

\begin{abstract}
Recently, the demands of composite materials used in various engineering applications are growing higher because of their outstanding mechanical and thermal properties. This study represents an experimental investigation to determine mechanical properties of Al-based composites materials using $\mathrm{Cu}$ and $\mathrm{SiC}$ as reinforcement. Al-30-wt\%-Cu, Al-40-wt\%-Cu, Al-30-wt\%-SiC, and Al-40wt $\%$-SiC composite bars were fabricated using stir casting process to ensure uniform distribution of reinforced elements. The composite bars were prepared into required shape to conduct test for evaluating mechanical properties. Al-40-wt\%-Cu shows improved properties such as, hardness, strength, and impact energy absorption than Al-30-wt\%-Cu due to more presence of $\mathrm{Cu}$ content. Al-30-wt\%-Cu and $\mathrm{Al}-40-\mathrm{wt} \%-\mathrm{Cu}$ bars showed improved mechanical properties than both $\mathrm{Al}-30-\mathrm{wt} \%-\mathrm{SiC}$ and $\mathrm{Al}-40-\mathrm{wt} \%-\mathrm{SiC}$. It is also seen that $\mathrm{Al}-30-$ wt $\%-\mathrm{Cu}$ and $\mathrm{Al}-40-\mathrm{wt} \%-\mathrm{Cu}$ showed high hardness, yield strength, and impact energy absorption compared to $\mathrm{Al}-30$-wt $\%-\mathrm{SiC}$ and $\mathrm{Al}-$ $40-\mathrm{wt} \%-\mathrm{Cu}$ respectively. On the other hand, $\mathrm{Al}-30-\mathrm{wt} \%-\mathrm{Cu}$ is 3.5\% lightweight than $\mathrm{Al}-30-\mathrm{wt} \%-\mathrm{SiC}$ and $\mathrm{Al}-40-\mathrm{wt} \%-\mathrm{Cu}$ is $2.11 \%$ lightweight than $\mathrm{Al}-40-\mathrm{wt} \%-\mathrm{SiC}$. Al-30-wt\%-Cu and $\mathrm{Al}-40-\mathrm{wt} \%-\mathrm{Cu}$ showed improved specific hardness, specific yield strength, and specific impact energy absorption compared to Al-30-wt\%-SiC and Al-40-wt\%-Cu respectively. In addition, Al-40-wt\%-Cu showed better mechanical properties among the bars.
\end{abstract}

Keywords: Metal matrix composites; Reinforcement; Stir Casting; Hardness; Strength; Impact Energy.

This work is licensed under a Creative Commons Attribution-Non Commercial 4.0 International

\section{Introduction}

Modern arena is moving forward positively by remarkable changes, inventions, and innovations in materials development with the advancement of science and technology. Like, many great attempts and researches have been carried out in order to improve mechanical and thermal behaviors of materials [1]. Many studies were performed to accomplish the growing needs of light-weight materials with outstanding performance in automotive, aviation, naval, shipbuilding, sports goods, biomedical equipment, prime movers, micro structure, and space industries. Composite metals have been attracted by the researchers and metallurgists to replace conventional materials for their improved mechanical and tribological behaviors such as, high strength to weight ratio, tensile and compressive behaviors, hardness, stiffness, durability, yield strength, density, low thermal expansion coefficient, counteraction to corrosion, thermal diffusivity, and good resistance to wear [2]. Composite materials consist of two or more than two macro, micro, and nano sized particles differing in physical formation and chemical composition in a suitably made mixtures to achieve required properties [3]. It is known to all that two or more materials are combined together to make composites given that all materials possessing different mechanical and chemical characteristics. It produces an individual material which differs from the properties of parent components when they are combined. In composites, reinforcement particle is usually the load carrying particle and matrix is the weaker phase.

Reinforcement gives high strength, stiffness and rigidity which helps to support externally applied load of any engineering structure. The organic or inorganic matrices or binders keep up the position and bearing of reinforcements accordingly [4]. In addition, the reinforced particles improve stiffness and strength of products which develops huge structural load carrying capacity. Composite materials are categorized into three such as, metal matrix composites (MMC), polymer matrix composites (PMC), and ceramic matrix composites (CMC) according to the chemical nature [5]. Recently, metal composites have drawn huge interests of the researchers and metallurgists because of their physical, mechanical, electrical, and tribological behaviors. In addition, automotive, automation, and aerospace industries are searching for advanced functional light materials to meet the requirements which is leading to speedy advancement of MMC's. Pure aluminium and its various alloys are used as matrix phase whereas, different non-metallic and metallic elements such as, Copper, silicon carbide, aluminium oxide, and sulphar dioxide are used as reinforcement in Aluminium metal composites (AMC) [6]. It is noted that the reinforcements are added with parent materials according to different composition to improve mechanical behaviors like hardness, impact energy absorption, stiffness, and strength of materials to meet requirements. Composite materials made from aluminium alloys with various reinforcements are widely used in many sophisticated engineering applications because of their outstanding properties as compared to others. [7]. AMC's are fabricated by varying proportion of reinforced particles and chemical composition of Aluminium and tested experimentally to get clear indication about changing of properties. For this consequences, Laplanche et al. [8] studied microstructures and mechanical behaviors of Al-based composite materials using $\mathrm{Cu}-\mathrm{Fe}$ particles as reinforced at different composition and, Sohn et al. [9] experimented on $\mathrm{Al}-\mathrm{Cu}$ based dendrite-ultrafine 
composites to analyze mechanically and micro-structurally. Kim et al. [10] fabricated a hierarchical multi-phase composites using $\mathrm{Al}-\mathrm{Ni}$ based intermetallic compounds in the $\mathrm{Al}-\mathrm{Cu}-\mathrm{Si}-\mathrm{Ni}$ alloy system also studied microstructural condition and mechanical behaviors. Viswanath et al. [11] investigated mechanical and creep behaviors of AZ91-SiCp composites fabricated by stir casting. Steinman et al. [12] studied experimentally and theoretically Al-based composite materials using its different grade alloys as reinforcements. AMC's are fabricated and produced in cost effectively and its applications are expanding rapidly due to cost effective manufacturing process. On the contrary, titanium shows better properties compared to other technological metals but it is rarely used in fabricating composites because of its high price and low tribological properties.

Huang et al. [13] suggested to use Al metal composites instead of $\mathrm{Fe}, \mathrm{Mg}, \mathrm{Ni}$, and $\mathrm{Cr}$ because of their comparative mechanical and chemical properties. $\mathrm{Al}-\mathrm{Cu}$ and $\mathrm{Al}-\mathrm{SiC}$ was selected in this study considering the above reasons. Researchers and metallurgists suggest many fabrication techniques of composites using different matrix and reinforcement. Fabrication of metal composites are categorized into five such as, liquidliquid phasing, liquid-solid phasing, solid-liquid phasing, deposition techniques, and suit processing according to type of mixture and processing temperature [14]. It is noted that stir casting is one of the simplest and most economical methods for fabrication of composite materials except some technical difficulties. Gopalakrishnan et al. [15] studied of making and wear analysis of composites using AA 6061 graded titanium carbide as reinforcement particulates by enhanced stir casting method. Raghuvaran et al. [16] investigated mechanical behaviors of A17075-SiC composites prepared by using stir casting technique and Vairamuthu et al. [17] studied the effects of some processing parameters such as, pressure, temperature, stirring speed and rpm in synthesized copper composites fabricated by stir casting technique. Authors represented improved mechanical, thermal, and chemical properties of composites materials rather than conventional materials in twostep and three-step stir casting method. With the author's best knowledge and experience from this study, fabrication cost is reduced to about one-third for making of composites by stir casting method for high volume production compared with other conventional method. Stir casting technique was utilized to fabricate $\mathrm{Al}-\mathrm{Cu}$ and $\mathrm{Al}-\mathrm{SiC}$ composite bars varying weight percentage of reinforcements. This study aims to evaluate mechanical properties namely hardness, yield strength, tensile strength, microstructure, impact energy absorption of $\mathrm{Al}-\mathrm{Cu}$ and Al-SiC composite bars so that this composites can be used in different emerging applications.

\section{Stir Casting Technology}

Recently, many promising techniques have been developed to fabricate metal composites using various particulate as reinforcement. This fabrication techniques are varied considerably depending on the type of reinforcement such as, powder metallurgy, spray decomposition, squeeze casting, liquid metal infiltration, and stir casting method etc. [18]. It is worthy to mention that stir casting process among the above mentioned techniques is used in fabricating metal composites due to its simple mechanism, flexibility, most economical route, high production rate, and low processing cost [19]. Usually, mother metals are heated above its melting point and particulate reinforcements are suffused into it by stirring which is a principal element of this process. It is noted that mixing strength, solidification rate, density difference, and wetting condition of given particles lead to proper distribution of particles in final mixture composites [20]. In addition, melting temperature, properties of the particulates added, mechanical stirrer's geometry, and placement of stirrer in the mixture determine the homogeneous distribution of particles in molten matrix. Due to technological advancement, double stir casting process can be termed as two-step mixing of final mixture, is being used in industry level to fabricate metal composites for using in different sectors [21]. In double stir casting process, the parent materials are heated above its melting temperature and kept them to cool down at temperature which is called liquidus and solidus point of semi-solid state. The preheated reinforced elements are added and mixed with parent materials at this point. After that, they are mixed thoroughly and the mixture is heated until a perfect liquid state is obtained. Surprisingly, the microstructures of composites are found to be more homogeneous in double stir casting process as compared with conventional stir casting. Double stir casting process has the capacity to break down gas layer remaining on particle's surface which can cause wetting condition between the particulates and molten metals that is the potential of this method. In addition, abrasive action of the particles due to their high melting viscosity is also responsible for breaking the gas layer at the time of mixing of particulates with parent materials in the semi-solid condition. Authors also designed and developed a triple-step stir casting process to fabricate and produce nano particles reinforced composites [21]. In this study, initially weighted Al bar was placed in the muffle furnace (Sante Furnace, STM-38-14-19) having a pot type crucible before completely melting. The furnace temperature was increased to around $700^{\circ} \mathrm{C}$ and kept at this condition about one and a half hour until $\mathrm{Al}$ bar melts completely. Afterward, copper powder were heated at around $820^{\circ} \mathrm{C}$ and almost, the same temperature was maintained until copper completely melts. $30-w t \%-C u$ powder which was used as reinforcement is preheated separately using muffle type furnace around $200^{\circ} \mathrm{C}$ about 30 minutes. The molten $30-w t \%-C u$ powder was poured into pure molten $\mathrm{Al}$ slowly. They were mixed thoroughly at $750^{\circ} \mathrm{C}$ until a perfect liquid state was obtained. Stirring operation was performed by a stirring rod for homogeneous distribution of $30-\mathrm{wt} \%-\mathrm{Cu}$ particles into molten $\mathrm{Al}$ metal and continued about one minute. Temperature of $\mathrm{Al}-\mathrm{Cu}$ mixture was maintained around $750^{\circ} \mathrm{C}$ for about 30 minutes after stirring. Dies were made of as desired shapes where $\mathrm{Al}-\mathrm{Cu}$ composites were poured and kept aside before they are completely solidified. The production method of $40-\mathrm{wt} \%-\mathrm{Cu}$ composites is same as $30-\mathrm{wt} \%-\mathrm{Cu}$ composites. Similarly, SiC powder was taken as reinforcement and was heated in atmospheric pressure at $850^{\circ} \mathrm{C}$ for two hours. It was showered into the molten pure $\mathrm{Al}$ by fixed rate at around $800^{\circ} \mathrm{C}$. $\mathrm{SiC}$ particles were heat treated so that they can form layer of silicon oxide on silicon carbide which fosters the placement of the $\mathrm{SiC}$ with Al. 30-wt\%-SiC powder and 40-wt\%-SiC which is used as reinforcement is preheated separately at atmospheric pressure around $200^{\circ} \mathrm{C}$ about 30 minutes and the 30 -wt $\%$-SiC, $40-\mathrm{wt} \%$ $\mathrm{SiC}$ was poured into molten pure $\mathrm{Al}$ metal slowly. A total of five metal composites bar of each composition were produced for testing purpose in order to evaluate mechanical behaviors. Average value from five specimens of each composite bar was reported in case of density, hardness, yield strength, and impact energy absorption. 


\section{Experimental Procedure}

\subsection{Hardness Test}

Brinell's hardness test was carried out by following ASTM A370 standard at room temperature. The specimens were machined from casted components having dimension of $40 \mathrm{~mm}$ $\times 40 \mathrm{~mm} \times 5 \mathrm{~mm}$. Hardness test was conducted in a standard Brinell hardness tester (HSM51, P. A. HILTON) with an equivalent constant load of $9.81 \mathrm{KN}(1000 \mathrm{~kg})$. Ball diameter of the Brinell hardness testing machine was $10 \mathrm{~mm}$.

\subsection{Tensile Test}

Tensile test was performed with ASTM A370 standard at room temperature. Samples of diameter $10 \mathrm{~mm}$ and length of 50 $\mathrm{mm}$ were tested in UTM (S12TO2, CNTROLS, Crosshead speed: $0.001-1000 \mathrm{~mm} / \mathrm{min}$ ) in order to perform tensile test. Crosshead speed ranging from about $10-30 \mathrm{~mm} / \mathrm{min}$ was used in testing the fabricated composite bars. Five samples of each Al30-wt $\%-\mathrm{Cu}, \mathrm{Al}-40-\mathrm{wt} \%-\mathrm{Cu}, \mathrm{Al}-30-\mathrm{wt} \%-\mathrm{SiC}$, and Al-40-wt\%$\mathrm{SiC}$ bars were tested to determine how much tensile strength is increased or decreased.

\subsection{Density Test}

$50 \mathrm{~mm} \times 50 \mathrm{~mm} \times 10 \mathrm{~mm}$ sized samples were weighted in a digital weight testing machine for measuring density.

\subsection{Microstructure Test}

The samples were polished properly using emery paper of grades starting from 280, 360, 500, and 1000 and followed by wafer polishing carried out by infixing silica gel with water. Finally, samples were undergone to etch using hydrochloric acid with distilled water by electrolytic methods. The microstructures of the specimens were analyzed by an optical microscope (OptuEdu, A13.2602-B, and Magnification: 100 x 400 x 1000x).

\subsection{Impact Test}

Charpy impact test was conducted to determine amount of absorbed impact energy during deformation. Hence, this absorbed energy indicates the measure of toughness in the samples which acts as a tool to study temperature depended brittle-ductile transition. Composites bars were shaped into 55 $\mathrm{mm} \times 10 \mathrm{~mm} \times 7.5 \mathrm{~mm}$ size to fit with Charpy impact test machine. Free fall angle $\alpha=67.5^{\circ}$, length of the hammer, $R=0.345 \mathrm{~m}$, mass of the hammer, $W=2.5 \mathrm{~kg}$, impact angle, $\beta=62^{\circ}$ for all composites was measured in the Charpy impact testing machine (HSM41, Hi-Tech Education).

\section{Results and Discussion}

Fig. 1 shows variation of hardness for all composites bar after addition of reinforcement. Al-40-wt\%-Cu shows about $4.34 \%$ greater hardness than $\mathrm{Al}-30-w t \%-\mathrm{Cu}$ whereas, $\mathrm{Al}-40-$ wt $\%$-SiC gives $4.6 \%$ greater hardness than $\mathrm{Al}-30-\mathrm{wt} \%-\mathrm{SiC}$ due to addition of $\mathrm{Cu}$ and $\mathrm{SiC}$ as reinforcements. It is noted that $\mathrm{Al}-$ $30-w t \%-C u$ shows $16.6 \%$ more hardness than $\mathrm{Al}-30-\mathrm{wt} \%-\mathrm{SiC}$ and $\mathrm{Al}-40-\mathrm{wt} \%-\mathrm{Cu}$ shows $16.4 \%$ more than $\mathrm{Al}-40-\mathrm{wt} \%-\mathrm{SiC}$. Although Kumar et al. [22] studied silicon nitride, authors showed the increase of hardness with addition of reinforcement and percentage of increment was about $20 \%$. This increment validates the theoretical background of composite materials. Kennedy et al. [23] mentioned hardness increases with density.
However, it is contradictory in this study. It is shown from Fig. 2 that $\mathrm{Al}-30-\mathrm{wt} \%-\mathrm{SiC}$ provides $3.5 \%$ greater density than $\mathrm{Al}-30$ wt $\%-\mathrm{Cu}$. On the contrary, Al-40-wt $\%$-SiC shows $2.11 \%$ greater density than $\mathrm{Al}-40-\mathrm{wt} \%-\mathrm{Cu}$. However, low density composite materials would be useful in application because of their lightweight. Hence, $\mathrm{Al}-\mathrm{Cu}$ composites are giving better properties than $\mathrm{Al}-\mathrm{SiC}$ in this study.

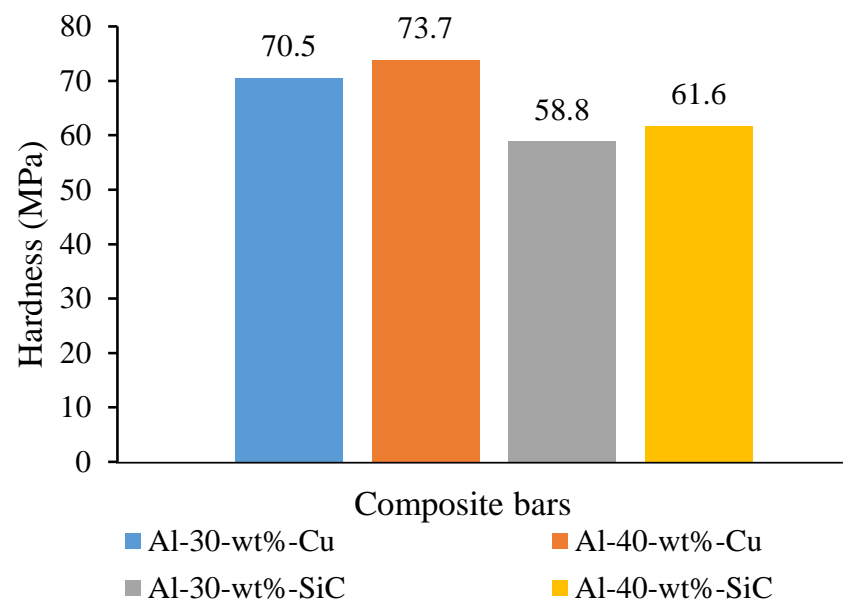

Fig. 1 Comparison of average hardness among the composite bars

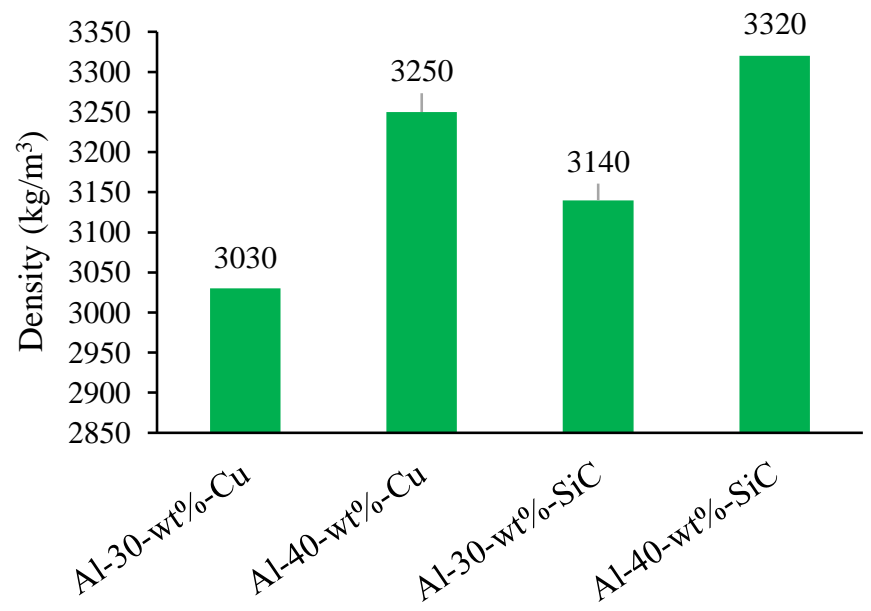

Fig. 2 Comparison of average density among the composite bars

In addition, specific hardness is another important property of composite metals. Specific hardness of all composite bars is shown in Fig. 3. Al-40-wt\%-Cu shows highest specific hardness among the composite bars and it can be concluded that Al-40$\mathrm{wt} \%-\mathrm{Cu}$ is the best composite among the fabricated bars in this study.

Tensile stress is gradually increased for all composites with strain for enhancement of higher reinforcement particles as shown in Fig. 4 and Fig. 5. In addition, increasing copper content with $\mathrm{Al}-30-\mathrm{wt} \%-\mathrm{Cu}$ and $\mathrm{SiC}$ with $\mathrm{Al}-30-\mathrm{wt} \%-\mathrm{SiC}$ composites results in the building of successive emollient between matrixes by the copper and silicon carbide particles [24]. Hence, it can be easily concluded that alloy creation, reinforcement, and good combination results in improving strength of metal composites. Raviraj et al. [25] reported that reinforcement enhances strengthening but the formability of the matrix reduces gradually; resulting in a lower level of strain. 


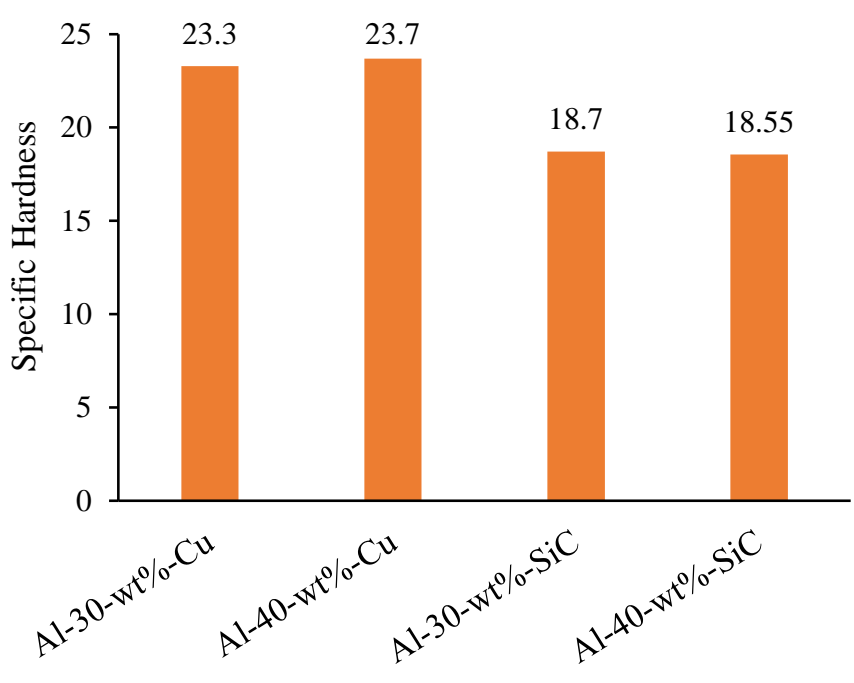

Fig. 3 Comparison of specific hardness among the composite bars

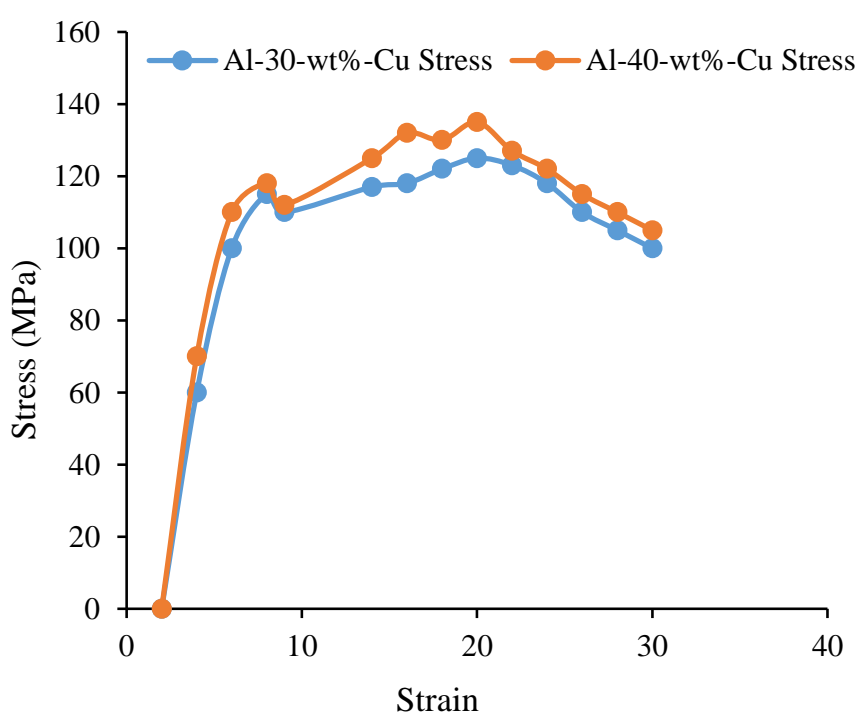

Fig. 4 Stress vs strain curve for Al-Cu composite bars

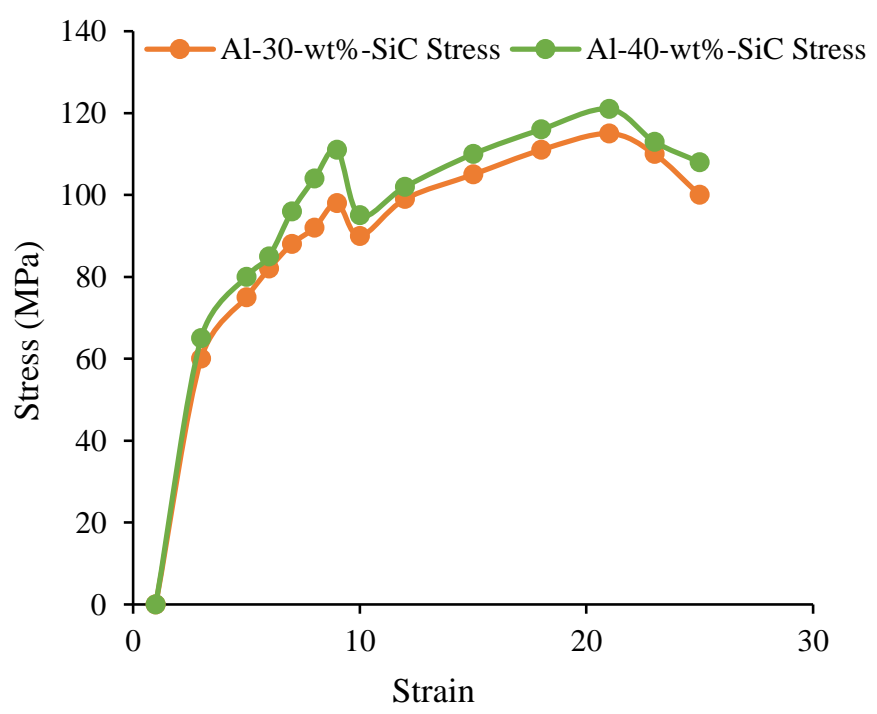

Fig. 5 Stress vs. strain curve for Al-SiC Composites bar.

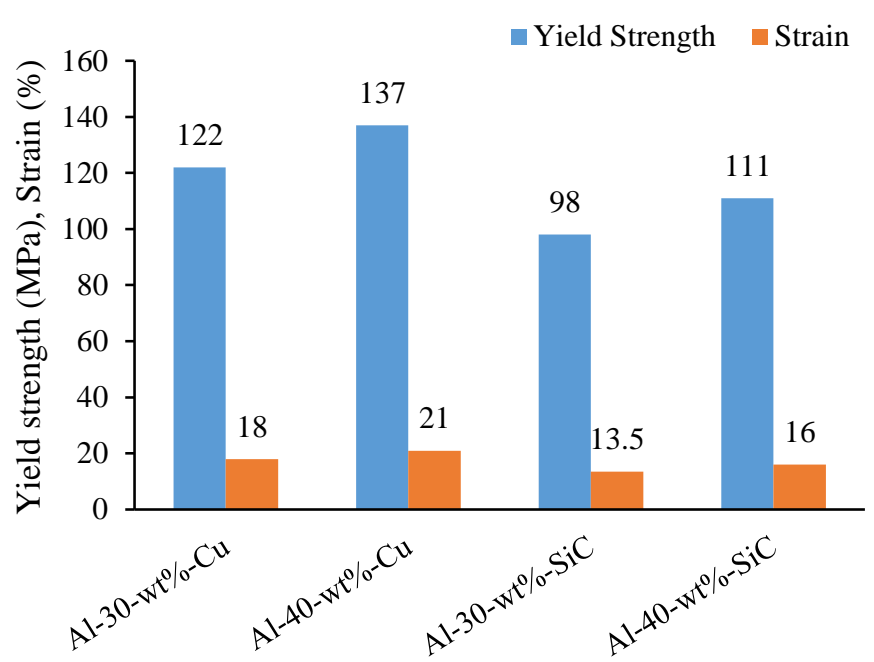

Fig. 6 Comparison of yield strength and strain between the composite bars.

Yield strength is an important mechanical property of materials that needs to be increased in composites with addition of reinforcement. It is shown in Fig. 6 that $11 \%$ yield strength has been increased in Al-40-wt\%-Cu compared to Al-30-wt\%$\mathrm{Cu}$ whereas, $11.8 \%$ has been increased in $\mathrm{Al}-40-\mathrm{wt} \%-\mathrm{SiC}$ than Al-30-wt $\%$-SiC. Surprisingly, Al-30-wt $\%-C u$ shows $19.7 \%$ greater yield strength than Al-30-wt\%-SiC and Al-40-wt\%-Cu provides $19 \%$ more yield strength than $\mathrm{Al}-40-\mathrm{wt} \%-\mathrm{SiC}$.

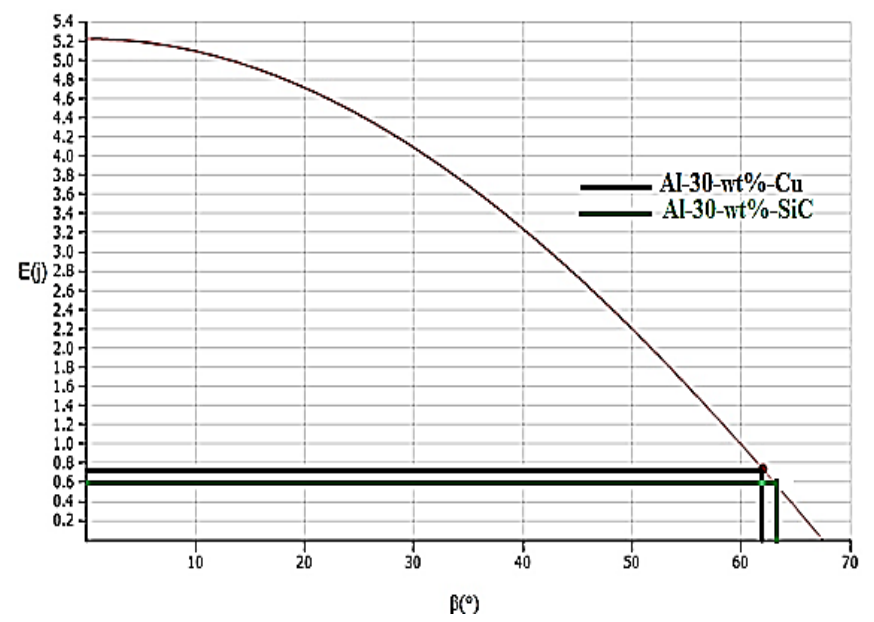

Fig. 7 Representation of impact energy absorption of $\mathrm{Al}-\mathrm{Cu}$ and Al-SiC composite bars.

In addition, $\mathrm{Al}-40-\mathrm{wt} \%-\mathrm{Cu}$ shows $4 \%$ improved specific yield strength than $\mathrm{Al}-30-\mathrm{wt} \%-\mathrm{Cu}$ and $\mathrm{Al}-40-\mathrm{wt} \%-\mathrm{SiC}$ shows $6.06 \%$ than Al-30-wt $\%-\mathrm{SiC}$. Al-40-wt\%-Cu shows highest specific yield strength among the composite bars. Hence, increment of yield strength validates the theoretical explanations. Another important property of materials is absorption of energy in impact testing. Impact absorption energy was calculated from established mathematical formula. The impact hammer traveled $62^{\circ}$ after impact and Al-30-wt\%-Cu composite bar absorbed 0.73 $\mathrm{J}$ energy at the time of impact as shown by red line in Fig. 7 and respectively. On the other hand, it would have absorbed total 5.2 $\mathrm{J}$ energy if the impact hammer stopped at the time of impact. It is shown in Fig. 7 and Fig. 8 that $\mathrm{Al}-30-\mathrm{wt} \%-\mathrm{Cu}$ absorbed energy, $\mathrm{E}=0.73 \mathrm{~J}, \mathrm{Al}-30$-wt $\%-\mathrm{SiC}$ absorbed $0.6 \mathrm{~J}, \mathrm{Al}-40-\mathrm{wt} \%-$ $\mathrm{Cu}$ absorbed $0.95 \mathrm{~J}$, and $\mathrm{Al}-40-\mathrm{wt} \%-\mathrm{SiC}$ absorbed $0.75 \mathrm{~J}$. 


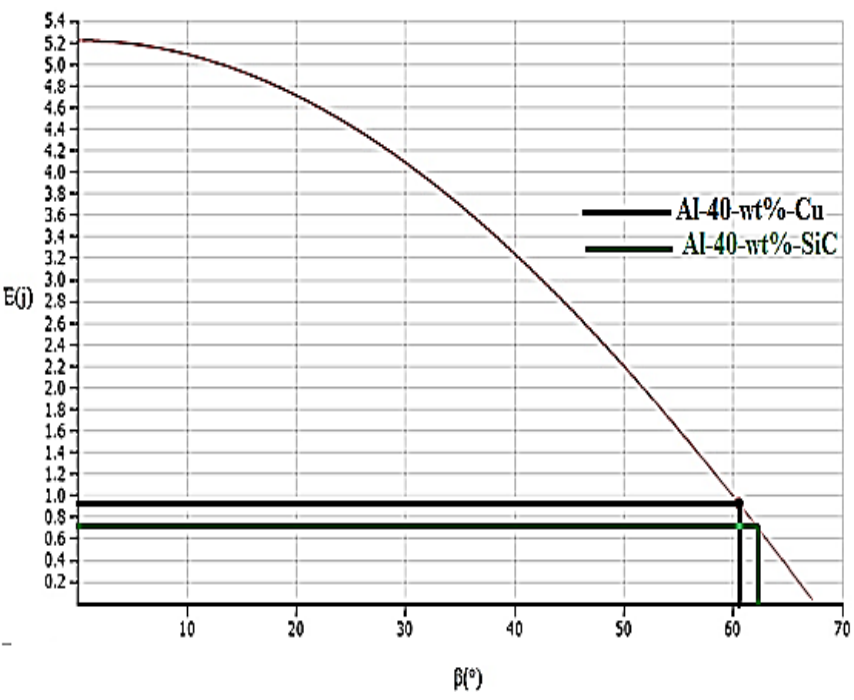

Fig. 8 Representation of impact energy absorption of $\mathrm{Al}-\mathrm{Cu}$ and $\mathrm{Al}-\mathrm{SiC}$ composite bars.

It is noted that $\mathrm{Al}-30-\mathrm{wt} \%-\mathrm{Cu}$ absorbed about $17.8 \%$ greater energy than $\mathrm{Al}-30-\mathrm{wt} \%-\mathrm{SiC}$ whereas, $\mathrm{Al}-40-\mathrm{wt} \%-\mathrm{Cu}$ absorbed about $21 \%$ greater energy than $\mathrm{Al}-40-\mathrm{wt} \%-\mathrm{SiC}$. It is worthy to mention that better tensile strength, hardness properties of $\mathrm{Al}-\mathrm{Cu}$ composite causes to greater energy absorption capability than Al$\mathrm{SiC}$ composite. In addition, presence of enhanced copper and $\mathrm{SiC}$ content increases energy absorption capability in $\mathrm{Al}-\mathrm{Cu}$ composites and $\mathrm{Al}-\mathrm{SiC}$ composites.

Fig. 9 represents the microscopic views of the $\mathrm{Al}-\mathrm{Cu}$ and $\mathrm{Al}-$ $\mathrm{SiC}$ composite bars fabricated in this study. This is somehow looking almost same microstructures of $\mathrm{Al}-30-\mathrm{wt} \%-\mathrm{Cu}$ with $\mathrm{Al}-$ $40-\mathrm{wt} \%-\mathrm{Cu}$ and microstructures of $\mathrm{Al}-30-\mathrm{wt} \%-\mathrm{SiC}$ with $\mathrm{Al}-40-$ $\mathrm{wt} \%-\mathrm{SiC}$.

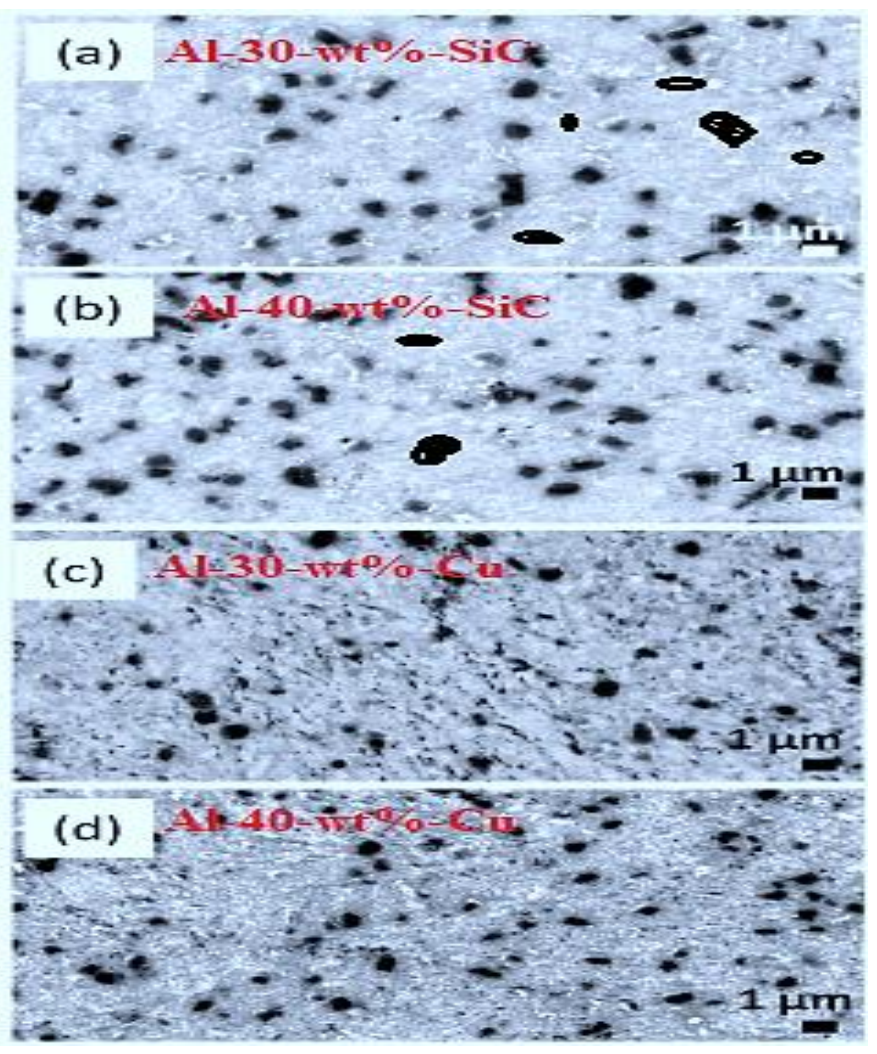

Fig. 9 Microscopic view of the composite bars
However, it is clearly indicating some differences between microstructures of $\mathrm{Al}-\mathrm{Cu}$ and $\mathrm{Al}-\mathrm{SiC}$ composite bars due to melting and mixing temperature difference and varied chemical compositions. Significant variation in properties of the $\mathrm{Al}-\mathrm{Cu}$ and Al-SiC composite bars could be due to those differences of the microstructures. Microstructures reveal very fine grain size of 1 micrometer because of the homogeneous distribution of reinforcement in the parent metals.

\section{Conclusion}

This study represents an experimental investigation on mechanical behaviors of $\mathrm{Al}-\mathrm{Cu}$ and $\mathrm{Al}-\mathrm{SiC}$ composites bar fabricated by using stir casting process. Stir casting technology is cost economic and easy process for mass production of metal composites. Density of metal composites increases for higher concentration of reinforcement. In addition, tensile strength, yield strength, hardness, impact energy absorption simultaneously was increased in both $\mathrm{Al}-\mathrm{Cu}$ and $\mathrm{Al}-\mathrm{SiC}$ composites with increasing reinforcement element. $\mathrm{Al}-\mathrm{Cu}$ composites represent better mechanical properties as compared to Al-SiC. Tensile strength, yield strength, hardness and impact energy absorption capability of $\mathrm{Al}-\mathrm{Cu}$ composites are higher than $\mathrm{Al}-\mathrm{SiC}$ composites. Al-40-wt\%-Cu shows $1.7 \%$ improved specific hardness and $4 \%$ specific yield strength compared to Al$30-w t \%-\mathrm{Cu}$ whereas, $\mathrm{Al}-40-\mathrm{wt} \%-\mathrm{SiC}$ shows $6.06 \%$ more specific yield strength and $0.8 \%$ specific hardness compared to Al-30-wt\%-SiC. Overall, Al-40-wt\%-Cu shows highest specific hardness, specific yield strength, and specific energy absorption among the fabricated composite bars.

\section{Acknowledgements}

Authors would like to express their gratefulness to Department of Mechanical Engineering, Chittagong University of Engineering \&Technology (CUET), Bangladesh for providing financial support and experimental facility to do this research work.

\section{Conflicts of Interest}

The authors declares no conflicts of interest.

\section{References}

[1] Rezaei, M.R., Albooyeh, A., Shayestefar, M. and Shiraghaei, H., 2020. Microstructural and mechanical properties of a novel Al-based hybrid composite reinforced with metallic glass and ceramic particles. Materials Science and Engineering: A, p.139440.

[2] Das, D., Chakraborty, V., Chaubey, A.K. and Nayak, R.K., 2018. Investigation on properties of $\mathrm{SiC}$ reinforced $\mathrm{Zn}-\mathrm{Mg}-\mathrm{Cu}$ based Al metal matrix composites-a case study. Materials Today: Proceedings, 5(9), pp.1987419882.

[3] Zhao, X., Gu, D., Ma, C., Xi, L. and Zhang, H., 2019. Microstructure characteristics and its formation mechanism of selective laser melting $\mathrm{SiC}$ reinforced $\mathrm{Al}-$ based composites. Vacuum, 160, pp.189-196.

[4] Sundaram, R.K., Sivashanmugam, N., Shameer, D., Deepak, R. and Saikrishnan, G., 2020. Experimental investigation of mechanical properties and drilling 
characteristics on polymer matrix composite materials. Materials Today: Proceedings.

[5] Pascu, C.I., Gheorghe, Ş., Rotaru, A., Nicolicescu, C., Cioateră, N., Roșca, A.S., Sârbu, D. and Rotaru, P., 2020. Ti-based composite materials with enhanced thermal and mechanical properties. Ceramics International, 46(18), pp.29358-29372.

[6] Kumar, U.K.A.V., 2017. Method of stir casting of aluminum metal matrix composites: a review. Materials Today: Proceedings, 4(2), pp.1140-1146.

[7] Bharath, V., Nagaral, M., Auradi, V. and Kori, S.A., 2014. Preparation of 6061Al-A12O3 MMC's by stir casting and evaluation of mechanical and wear properties. Procedia materials science, 6, pp.1658-1667.

[8] Laplanche, G., Joulain, A., Bonneville, J., Schaller, R. and El Kabir, T., 2010. Microstructures and mechanical properties of Al-base composite materials reinforced by $\mathrm{Al}-\mathrm{Cu}-\mathrm{Fe}$ particles. Journal of alloys and compounds, 493(1-2), pp.453-460.

[9] Sohn, S.W., Park, J.M., Kim, W.T. and Kim, D.H., 2012. Microalloying effect on the microstructure and mechanical properties in $\mathrm{Al}-\mathrm{Cu}$ based dendrite-ultrafine composites. Journal of alloys and compounds, 541, pp.1417. doi: 10.1016/j.jallcom.2012.06.127.

[10] Kim, J.T., Hong, S.H., Park, J.M., Eckert, J. and Kim, K.B., 2018. Microstructure and mechanical properties of hierarchical multi-phase composites based on Al-Ni-type intermetallic compounds in the Al-Ni-Cu-Si alloy system. Journal of Alloys and Compounds, 749, pp.205-210. doi: 10.1016/j.jallcom.2018.03.313.

[11] Viswanath, A., Dieringa, H., Kumar, K.A., Pillai, U.T.S. and Pai, B.C., 2015. Investigation on mechanical properties and creep behavior of stir cast AZ91-SiCp composites. Journal of Magnesium and alloys, 3(1), pp.16-22. doi: 10.1016/j.jma.2015.01.001.

[12] Steinman, A.E., Corthay, S., Firestein, K.L., Kvashnin, D.G., Kovalskii, A.M., Matveev, A.T., Sorokin, P.B., Golberg, D.V. and Shtansky, D.V., 2018. Al-based composites reinforced with AlB2, AlN and BN phases: experimental and theoretical studies. Materials \& Design, 141, pp.88-98. doi: 10.1016/j.matdes.2017.12.022.

[13] Huang, G., Hou, W., Li, J. and Shen, Y., 2018. Development of surface composite based on $\mathrm{Al}-\mathrm{Cu}$ system by friction stir processing: Evaluation of microstructure, formation mechanism and wear behavior. Surface and Coatings Technology, 344, pp.30-42.

[14] Santhanam, V., Dhanaraj, R., Chandrasekaran, M., Venkateshwaran, N. and Baskar, S., 2020. Experimental investigation on the mechanical properties of woven hybrid fiber reinforced epoxy composite. Materials Today: Proceedings. doi: 10.1016/j.matpr.2020.07.444.

[15] Gopalakrishnan, S. and Murugan, N., 2012. Production and wear characterisation of AA 6061 matrix titanium carbide particulate reinforced composite by enhanced stir casting method. Composites Part B: Engineering, 43(2), pp.302-308. doi: 10.1016/j.compositesb.2011.08.049.

[16] Raghuvaran, P., Baskaran, J., Aagash, C., Ganesh, A. and Krishna, S.G., 2020. Evaluation of mechanical properties of Al7075-SiC composites fabricated through stir casting technique. Materials Today: Proceedings. doi: 10.1016/j.matpr.2020.09.191.

[17] Vairamuthu, J., Stalin, B., Sivakumar, G.D., Fazil, B.M., Balaji, R. and Natarajan, V.A., 2020. The effect of process parameters for synthesized copper metal matrix using stir casting process. Materials Today: Proceedings. doi: 10.1016/j.matpr.2020.09.262.

[18] Satishkumar, P., Rakesh, A.I.J., Meenakshi, R. and Murthi, C.S., 2020. Characterization, mechanical and wear properties of Al6061/Sicp/fly ashp composites by stir casting technique. Materials Today: Proceedings. doi: 10.1016/j.matpr.2020.08.530.

[19] Kala, H., Mer, K.K.S. and Kumar, S., 2014. A review on mechanical and tribological behaviors of stir cast aluminum matrix composites. Procedia Materials Science, 6, pp.1951-1960.

[20] Alaneme, K.K. and Ajayi, O.J., 2017. Microstructure and mechanical behavior of stir-cast $\mathrm{Zn}-27 \mathrm{Al}$ based composites reinforced with rice husk ash, silicon carbide, and graphite. Journal of King Saud UniversityEngineering Sciences, 29(2), pp.172-177. doi: 10.1016/j.jksues.2015.06.004.

[21] Prabu, S.B., Karunamoorthy, L., Kathiresan, S. and Mohan, B., 2006. Influence of stirring speed and stirring time on distribution of particles in cast metal matrix composite. Journal of materials processing technology, 171(2), pp.268-273.

[22] Kumar, S.A., Vignesh, J.H. and Joshua, S.P., 2020. Investigating the effect of porosity on aluminium 7075 alloy reinforced with silicon nitride (Si3N4) metal matrix composites through STIR casting process. Materials Today: Proceedings. doi: 10.1016/j.matpr.2020.07.690.

[23] Kennedy, A.R., Karantzalis, A.E. and Wyatt, S.M., 1999. The microstructure and mechanical properties of $\mathrm{TiC}$ and TiB2-reinforced cast metal matrix composites. Journal of materials science, 34(5), pp.933-940. doi: 10.1023/A:1004519306186.

[24] Jing, S.U.N., WANG, X.Q., Yan, C.H.E.N., Fei, W.A.N.G. and WANG, H.W., 2020. Effect of $\mathrm{Cu}$ element on morphology of TiB2 particles in TiB2/Al- $\mathrm{Cu}$ composites. Transactions of Nonferrous Metals Society of China, 30(5), pp.1148-1156. doi: 10.1016/S10036326(20)65285-2.

[25] Raviraj, M.S., Sharanprabhu, C.M. and Mohankumar, G.C., 2014. Experimental analysis on processing and properties of Al-TiC metal matrix composites. Procedia Materials Science, 5, pp.2032-2038. doi: 10.1016/j.mspro.2014.07.536. 